\section{International Journal \\ of \\ English Studies}

IJES

http://revistas.um.es/ijes

\title{
Vocative and diminutive forms in Robert Louis Stevenson's fiction: A corpus-based study
}

\author{
MARINA DOSSENA \\ Università degli Studi di Bergamo
}

Received: 27 January 2012 / Accepted: 25 June 2012

\begin{abstract}
This paper takes a corpus-based approach to the study of vocative and diminutive forms in the prose fiction and drama of the Scottish author Robert Louis Stevenson. In such texts, the coexistence, and indeed the coalescence, of Scots and (Scottish Standard) English is one of the most important traits in their author's distinctive style. The aim is to assess whether the use of diminutive forms together with vocative ones may constitute a syntactic unit in which semantic and pragmatic values are mutually reinforced. In addition to a specially-compiled corpus of Stevenson's texts, the investigation will consider occurrences of the same structure in the imaginative prose section of the Corpus of Modern Scottish Writing, which will be used as a control corpus.
\end{abstract}

\section{KEYWORDS:}

Morphology, pragmatics, corpus linguistics, Scots, (Scottish Standard) English

\section{RESUMEN}

El presente trabajo adopta un enfoque basado en corpus con el objetivo de estudiar las formas vocativas y diminutivas en el teatro y en la ficción en prosa del autor escocés Robert Louis Stevenson. En estos textos, la convivencia y, de hecho, la fusión de escocés e inglés (estándar hablado en Escocia) es uno de los rasgos caracterizadores del estilo del autor. Así pues, el presente trabajo pretende evaluar si el uso de los diminutivos, junto con los vocativos, logra constituir una unidad sintáctica en la que los valores semánticos y pragmáticos se refuerzan mutuamente. Además de un corpus compilado especialmente con textos de Stevenson, la investigación tendrá en cuenta la presencia de la misma estructura en la sección de prosa imaginativa del Corpus of Modern Scottish Writing, que será utilizado como corpus de control.

PALABRAS CLAVE:

Morfología, pragmática, lingüística de corpus, escocés, inglés (estándar hablado en Escocia)

*Address for correspondence: Dipartimento di Lingue, Letterature Straniere e Comunicazione. Università degli Studi di Bergamo, Piazza Rosate 2, 24129 Bergamo, Italy. Tel: 0039 0352052747; Fax: 00390352052789 ; Email: marina.dossena@unibg.it 


\section{INTRODUCTION}

In line with other pieces of research in this issue, this paper aims to take a corpus-based approach to literary studies, in order to identify patterns of usage which may be indicative of stylistic specificity on the one hand, and of greater or lesser correspondence with codified forms on the other. A corpus-based methodology presents undoubted advantages in this respect: while the tools currently available for scholarly investigations ensure reliable quantitative findings, these can be supplemented with accurate qualitative readings which allow stylistic assessments to be both convincing and scientifically valid.

For the purposes of this study, the drama and prose fiction of Robert Louis Stevenson have been selected for a variety of reasons: not only have these works been extremely popular for decades -which may be indicative of their author's successful style- but they also show a remarkable complexity in terms of linguistic choices, not least in all those cases in which Scots and English are employed alongside each other in the same text. As Dossena (in preparation) has shown, Stevenson's use of Scots and English (in particular, of Scottish Standard English, henceforth SSE) was both very skilful and very accurate, switching from one language to the other in ways that suited style, pace and rhythm, thus contributing to a better definition of both characters and settings.

Stevenson was also aware of the potential difficulties that any writer of Scots would run into when attempting to achieve consistent spelling and usage: in the Preface to Underwoods (1887), he commented quite extensively on this point. His metalinguistic analyses were always put to good use in his poetry and, particularly, in four of his most successful novels (Kidnapped, 1886; The Master of Ballantrae, 1889; Catriona, 1893; and Weir of Hermiston, 1896) and in two short stories (Thrawn Janet, 1881, entirely written in Scots, and The Merry Men, 1887). But Scots also occurred in the humorous exchanges between Stevenson and Charles Baxter, his life-long friend, lawyer and business agent, under the interchangeable pseudonyms of Thomson and Johnson: see Booth and Mehew (1994/1995: passim).

Stevenson was writing at a time when the prescriptive tradition in phonology, grammar and vocabulary still considered Scotticisms both barbarous and vulgar, but had no objection to their use in poetry (Dossena, 2005: 116-133). In fact, a certain Anglo-Saxonist fashion tended to see northern varieties as closer to the 'original purity' of the language, because they had been less tainted by Norman influences and their Latinate syntax and vocabulary (Dury, 1992). Stevenson, however, had a much more flexible attitude towards language. He did not argue in favour of language purity, whether this referred to a supranational standard or to a more local variety: instead, he argued very strongly in favour of expressiveness, and this is often achieved by more than code-switching between English and Scots. In the texts under investigation it may be more appropriate to talk about actual 'code-mixing', as stories are interpolated in other stories (as in the case of Tod Lapraik's Tale in Catriona), metaphors and 
similes evoke folk tales and ballads, and speakers of different social classes converse in both languages (as we see in Weir of Hermiston).

The range of features that could be selected for corpus investigation is thus very broad. In the next sections, however, this study will concentrate on the co-occurrence of vocative and diminutive forms, in order to analyze their specificity in Stevenson's usage. After an overview of diminutive forms in Scots and SSE as observed in present-day usage, the current analysis will focus on the occurrence of such forms in a specially-compiled corpus of Stevenson's prose fiction and drama; particular attention will be given to the texts listed above, on account of the greater frequency with which Scots forms occur throughout them. Henceforth they will be abbreviated as follows: Kidnapped (K), The Master of Ballantrae (MB), Catriona (C), Weir of Hermiston (WH), Thrawn Janet (TJ) and The Merry Men (MM). As a control corpus, this investigation will employ the imaginative prose section of the Corpus of Modern Scottish Writing (CMSW). Where appropriate, reference will also be made to the Dictionary of the Scots Language (DSL) ${ }^{1}$ and to the Oxford English Dictionary (OED).

\subsection{Diminutive forms in Scots and Scottish Standard English (SSE)}

Scholars have often pointed out the remarkable lack of diminutive forms in most varieties of English, with the exception of SSE and Australian English, as opposed to more frequent occurrences in Scots. ${ }^{2}$ In particular, Dorian (1993: 134) stresses the diffusion of diminutive forms in North East Scots and briefly investigates its possible connection with East Sutherland Gaelic (ESG), identifying "a corresponding freedom of occurrence for diminutives which does not seem to exist in western dialects of Gaelic". Dorian (1993: 134) further reports that Gaelic speakers from the Isle of Mull do not use many diminutives in free conversation, nor do they produce them in elicitation contexts which had "quite reliably produced them in East Sutherland"; the same author quotes one Mull speaker, according to whom "the way ESG speakers attached diminutives liberally to body-part terms sounded childish to him, like a form of baby-talk".

As a matter of fact, linguists have identified the sound-iconism of [i], which is typically found in diminutive forms (as in Italian gattino, Spanish gatito, German Mausi, Scots beastie), as an element that contributes to the emotional colouring of these uses. This colouring is typically associated with child-centred speech situations and is transferred to petcentred and lover-centred speech situations. In this respect, Dressler and Merlini Barbaresi (1994: 196) refer to “Freud's assertions on the 'kindischen Gesten aller Verliebten'” (i.e., the childlike gestures of all lovers), and the linguistic parallelism is clearly exemplified by Bulloch (1921/1970: 140-142), who quotes rhymes that express both smallness and endearment through the application of diminutives not only to the addressee, but also to other items that set the context. As an example of child-centred speech situations, Bulloch (1921/1970: 140) presents the following lines, in which the sequence of diminutives is quite 
remarkable, as almost every noun has a diminutive suffix (emphasis added here and elsewhere):

Dance to your daddie, my bonnie laddie.

Dance to your daddie, my bonnie lamb!

And ye'll get a fishie in a little dishie

Ye'll get a fishie when the boat comes hame.

For the lover-centred speech situation Bulloch then quotes the broadside ballad 'Come under my plaidie' (1921/1970: 142) ${ }^{3}$, in which the recipient is consistently addressed as "dear lassie”.

In Robert Burns's poetry, which since Late Modern times has grown to epitomize Scots verse, instances of diminutive forms as endearing ones occur, most notably, in his 1785 poem 'To a Mouse', which opens with the following lines:

Wee, sleekit, cow'rin, tim'rous beastie,

$\mathrm{O}$, what a panic's in thy breastie!

But lasses also feature in many of his songs, and -on account of the homophony between the plural of both the plain and the diminutive forms of the noun lass- the sound iconism of the diminutive may appear to be more frequent than written texts would suggest. Compare, for instance, the chorus of this 1783 song:

Green grow the rashes, $\mathrm{O}$;

Green grow the rashes, $\mathrm{O}$;

The sweetest hours that e'er I spend,

Are spent amang the lasses, $\mathrm{O}$.

With the chorus of this 1794 one, in which the nominalized adjective dearie also displays the endearment suffix -ie:

Lassie wi'the lint-white locks,

Bonie lassie, artless lassie,

Wilt thou wi' me tent the flocks,

Wilt thou be my Dearie, O?

On the other hand, diminutives may also occur in expressions of irony and even sarcasm. Bulloch (1921/1970: 146) finds that while "the diminutive is admirable for expressing the physical smallness of a child, and the child quality in the things we love, so it represents equally well all kinds of spiritual smallness and meanness". This contemptuous use is allegedly epitomized in the Jacobite song 'The Wee German Lairdie', whose opening lines are "Wha the de'il ha'e we gotten for a king But a wee, wee German lairdie?” (Bulloch, 1921/1970: 148). Interestingly, this is in sharp contrast with the fact that, to this day, the most important figure in the last Jacobite rebellion, in 1745, is popularly known as "Bonnie Prince 
Charlie", a label in which the hypocoristic form of the name rhymes internally with the familiar Scots qualifier bonnie, and well-known Jacobite tunes have titles like 'Charlie's my darling' and 'Wha'll be king but Charlie?'.

As for the formation of diminutives, the most productive suffix is certainly -ie; other Scots diminutive suffixes, such as -ock, -kin and -ag do not seem to occur in SSE. However, their usage is described in Aitken (1992: 896) and -ag seems specially interesting because it typically occurs in the North, implying Gaelic influence on lexis. It also influences morphology, because - $a g$ is the feminine diminutive suffix (the equivalent masculine suffix is -an), so "nominal gender assignment gets an enormous boost in the dialect" (Dorian, 1993: 134). Besides, suffixes may also co-occur, as in lassockie, and they may be reinforced through the use of an attributive adjective like wee or, as we have seen above, bonnie. Indeed, such adjectives may almost function as a cataphoric reference to the diminutive form.

Forms which are restricted in their domain also prove interesting, because they may be more or less transparent on the semantic level, and may thus contribute to the definition of inand out-groups. As for the morphological structure of such items, a range of possibilities appears to be viable: for instance, gabsie (= talkative person) joins a noun (gab) and a diminutive suffix with an epenthetic consonant, thus producing an almost iconic new item; grippie (= avaricious) exploits the same strategy, though the reduplication of $<\mathrm{p}>$ is simply a spelling feature meant to indicate vowel length, and applies it to a verb (grip); gaffie (=grandfather), instead, shows the kind of phonological simplification that might be expected in baby-talk, again providing an iconic counterpart of the word. Tulloch (1997: 401) also identifies the formation of adjectives from nouns and verbs, and of nouns from verbs and other nouns. Suffixation is often accompanied by reduplication, clipping, or both: this is the case of eeksie-peeksie ( = on an equality, much alike), which derives from equal. Clipping and suffixation, instead, are generally used for proper names and nouns. In everyday spoken usage, hypocoristic forms like Davie, Jamie, Dougie, Lizzie, etc. also occur -Jimmie can actually be found as a familiar way of addressing a stranger (see DSL: Jimmie, s.v. in the SNDS2 section). Nor are cities exempt from the attribution of familiar nicknames based on diminutive forms: Auld Reekie, i.e. Edinburgh, has perhaps been the most famous instance since Robert Fergusson used it in his 1772 poem.

Clipping and suffixation may be integrated with phonological adjustments: thus, as in the case of grippie, phonological rules concerning vowel length are at the basis of the reduplication of $<\mathrm{n}>$ in jannie ( $<$ janitor) and of the substitution of the voiced fricative $/ \mathrm{v} /$ with its voiceless counterpart /f/ in scaffie (< scavenger). As a matter of fact, Scots seems to extend diminutives from proper names to nouns indicating jobs. Though this phenomenon is not discussed by Aitken (1984a; 1984b), Miller (1993) or McClure (1994), it is mentioned by McClure (1987; 1993) and Milton (1992); the most thorough description, however, is offered by Tulloch (1997). McClure's discussion of the features of Lallans and Doric in North- 
Eastern poetry (1987: 218) associates the "use of the characteristic -even stereotypicaldiminutive" to the latter. Indeed, numerous instances may be identified in Fenton (1995), also in adverbial phrases, such as a filie back (= some time ago: Fenton, 1995: 84) or a bittie (= a little: Fenton, 1995: 74). But a relatively high frequency of diminutives is also found in SSE, where we find postie, gamie, fiddlie, pipie, and many other similar items. Euphemistic nouns may also be formed from names, as in the case of shankie (= lavatory), from the brand name of the product.

The importance of diminutive forms is also shown in their role in the formation of compounds: Tulloch (1997: 409) refers to Macafee's study of Glaswegian (1994) for the case of midgie (= refuse collection arrangements), which has become part of midgie-man (= dustman) and midgie-motor (= the dustman's lorry). These items occur in several instances in spoken usage in the Scottish Corpus of Text and Speech (SCOTS), which comprises documents dating from 1945 to the present and highlights an important trait of the Scots-SSE language continuum; two examples are given below:

1. Come on ben, we'll go ben the living room. [...] I'll check if the postie's been

2. Jonsar Eck didnae like tae say he hid a fower taed fork an wis a bittie mair upmarket than the mannie.

Already in nineteenth-century usage, however, a very interesting instance is actually found in Stevenson's poetry; in A Child's Garden of Verses (1885) the protagonist cheerily welcomes the arrival of the lamplighter with the familiar nickname of Leerie:

My tea is nearly ready and the sun has left the sky;

It's time to take the window to see Leerie going by;

For every night at teatime and before you take your seat,

With lantern and with ladder he comes posting up the street.

Now Tom would be a driver and Maria go to sea,

And my papa's a banker and as rich as he can be;

But I, when I am stronger and can choose what I'm to do,

O Leerie, I'll go round at night and light the lamps with you!

For we are very lucky, with a lamp before the door,

And Leerie stops to light it as he lights so many more;

And O! before you hurry by with ladder and with light;

O Leerie, see a little child and nod to him to-night!

The nickname is also found in the SCOTS corpus, in which the following rhyme is recited by the protagonist of a short story:

Leerie leerie licht the lamps

Langlegs an crookit shanks. 
Moving from word formation to syntactic and pragmatic issues, it may be particularly interesting to focus on the way in which the hypocoristic, diminutive forms of proper names are used in vocative forms. In such cases they may occur together with or independently of other epithets such as lad or lass, thus possibly affecting the illocutionary force of the appeal. It is, then, on this syntactic pattern that the next sections will concentrate.

\section{METHOD}

As the research question investigated in this study concerns the pragmatic relationship existing between diminutive and vocative forms, the current analysis will consider the combination of hypocoristic forms like Charlie, Chrissie, Davie, Jamie, etc. and nouns like boy, girl, kid, lad(die), lass(ie), man, quean and woman, and which may be separated by a comma (thus functioning independently) or may occur together as one syntactic unit in the same vocative form.

Before searching for such occurrences in the Stevenson corpus and in CMSW, the DSL entries for the nouns listed above were analyzed in order to assess their semantic and pragmatic values when used in forms of address. While boy, kid, girl and lad(die) do not seem to have any relevant entries concerning vocative forms, the following is observed in the other entries, for which a few significant quotations are cited below:

Lass (SND) 6. A familiar term of address to a woman, e.g. one's wife, sweetheart, or to a female animal. *Ayr. 1796 Burns A red, red Rose ii.: As fair art thou, my bonie lass, So deep in luve am I. [...] *Abd. 1909 G. Greig Main’s Wooin’ 7: Oh, come awa’, Maggie, lass! I wis jist lookin’ for ye.

Man (DOST) h. In the vocative or parenthetically, usually implying familiarity, condescension, contempt or impatience. [...] 'Wo is me,' quod scho, 'quhair will ze, man?' Dunb. lxxv. [...] 'I had nather God nor the devill, man, before my eyes,' said the King [James VI], 'but my owne defence'; 1600 Calderwood VI. 156.

Quean (SND) 2. A female child, a girl up to the end of her schooldays, esp. in dim. form and in phr. loons and quines, boys and girls (...). Also used vocatively as a term of endearment. [...] *Cai. 1869 M. Maclennan Peasant Life 155: Troth wull I, bairn, but what's yer name, ma queanie?

Woman (SND) 2. As a familiar form of address, but not, as in St. Eng., restricted to derogatory or jocular usage, occas. applied to a little girl [...] *Dmf. $1824 \mathrm{~W}$. McVitie Tales for the Ingle-cheek II. 11: He thus addressed his gudwife: "Wha think ye, Mary, my woman, I saw in Glasgow to-day?” *Uls. 1879 “Robin” Hum. Readings 35: Oh, Maggie, womun, but that's guid. *Slk. 1894 J. Bathgate Aunt Janet’s Legacy 69: Lassie, did ye never see a sandglass? wummin, ye're as ignarint as a peat.

It may therefore be interesting to compare such comments with those in the OED, in order to get a more complete picture: of course, uses of boy and lass(ie) to address pets are beyond the scope of this analysis, though the latter became world famous after the success of 
the Lassie Come-home stories, films and television series in the second half of the twentieth century. As quotations are numerous for each item, only a few significant ones are presented together with each entry:

Boy 3.c. In playful, affectionate, or slighting use: a young man, a fellow. Also as a form of address. [...] e. Appended to a male forename (esp. as a form of address). 4. a. As a familiar form of address to a man. Formerly often with my, dear, old (see also old boy $\mathrm{n}$. 1); this usage is now generally considered old-fashioned or upper-class. $1728 \mathrm{I}$. Dandridge Like will to Like I. xii. 27 Ah dear Billy-boy, There wou'd be Days for you and I! 1889 B. Harte Cressy xiii. 278 'What is it, Johnny boy?’ asked the master tenderly. [...] 2008 Gold Coast Bull. (Austral.) (Nexis) 3 Jan., Davey boy, your time was the result of your choices.

Girl 4. Used as a form of address to a girl or woman. See also my girl at my adj. 2a. Often (esp. in later use) in informal contexts, implying intimacy or friendship between the speaker and the person addressed. 1562 A. Brooke tr. M. Bandello Tragicall Hist. Romeus and Iuliet 19 She saith with smyling face. Good newes for thee my gyrle good tidinges I thee bring. [...] 1800 W. Dunlap tr. A. von Kotzebue False Shame ii. vi. 28 Why, girl, thou art become tall and beautiful. [...] 2006 P. Williams Rise and Fall Yummy Mummy xxxviii. 256 You're not married yet, girl.

Lad 2. a. A boy, youth; a young man, young fellow. Also, in the diction of pastoral poetry, used to denote 'a young shepherd'. In wider sense applied familiarly or endearingly (sometimes ironically) to a male person of any age, esp. in the form of address my lad. 1856 R. M. Ballantyne Snowflakes and Sunbeams xxviii. 390 What did you say struck you, Harry, my lad?

Man IV. Vocative uses. 16. As vocative or as int., introducing a remark or parenthetically. a. Used to address a person (usually a man, but sometimes a woman or child) emphatically to indicate contempt, impatience, exhortation, etc. Now somewhat arch. b. Eng. regional (north.), Sc., Irish English, Welsh English, and S. Afr. colloq. Also, esp. in 20th cent., in Caribbean English and among African-Americans. Used to address a person (in many varieties of English, irrespective of sex) parenthetically without emphasis to indicate familiarity, amicability, or equality between the speaker and the person addressed. Now sometimes with loss of vocative force. 1826 B. Disraeli Vivian Grey II. iv. iv. 198 Hah! what—what's all this! Here, read it, read it, man.

Woman 5. As a form of address, used emphatically to indicate contempt, impatience, exhortation, etc. (cf. man n. ${ }^{1}$ 16.). In later use chiefly regional and generally considered offensive. 1860 G. A. Sala Baddington Peerage I. iii. 63 'Will you hold your tongue, woman?' her husband cried out 'Woman! hold my tongue! This language to me!'

The dictionary entries are clearly asymmetrical, as they concern different varieties and therefore different uses. What is interesting, however, is the way in which these nouns appear to be used in relatively marked pragmatic contexts, in which their use as a vocative form appears to add disparaging or endearing values -precisely the kind of values that, as we saw above, diminutive forms may also express. The next step in the current investigation is therefore to analyze how these forms are employed in both the Stevenson (RLS) corpus and in CMSW, the control corpus. 
The RLS corpus, comprising a total of 1,463,512 words, was assembled collecting volumes 4, 5, 6, 7, 8, 10, 11, 12, 13, 15, 17, 19, 20, and 21 of the Swanston edition of Stevenson's works, in which his prose fiction and drama feature ${ }^{4}$. While other editions could be consulted (and indeed reference will be made to them where applicable), the homogeneity of this collection was thought to be sufficiently valid for the creation of a dedicated corpus (see Dury, n.d.).

As for the control corpus, the imaginative prose section of CMSW comprises 18 documents published between 1765 and 1927 (5.06\% of corpus), for a total word count of 1,691,673 (31.13\% of corpus). For the purposes of this study, however, only nineteenthcentury texts were taken into consideration, and they are listed in Table 1 below. MB was excluded from the control corpus, so as to avoid any circularity of data.

\begin{tabular}{|l|l|r|r|}
\hline \multicolumn{1}{|c|}{ Title } & \multicolumn{1}{c|}{ Author } & Year & \multicolumn{1}{c|}{ Word count } \\
\hline The Three Perils of Women, Vol. 1 & Hogg, James & 1823 & 62,486 \\
\hline The Three Perils of Women, Vol. 2 & Hogg, James & 1823 & 61,635 \\
\hline The Three Perils of Women, Vol. 3 & Hogg, James & 1823 & 67,610 \\
\hline Private Memoirs and Confessions of a Justified Sinner & Hogg, James & 1824 & 84,088 \\
\hline Noctes Ambrosianae, Vol. 3 & Wilson, Professor John & 1864 & 145,182 \\
\hline Noctes Ambrosianae, Vol. 4 & Wilson, Professor John & 1864 & 125,203 \\
\hline Noctes Ambrosianae, Vol. 1 & Wilson, Professor John & 1865 & 155,951 \\
\hline Noctes Ambrosianae, Vol. 2 & Wilson, Professor John & 1865 & 170,843 \\
\hline David Elginbrod & Macdonald, George & 1871 & 173,827 \\
\hline Johnny Gibb of Gushetneuk & Alexander, Mr William & 1873 & 115,230 \\
\hline \multicolumn{2}{|c|}{} & Total & $\mathbf{1 , 1 6 2 , 0 5 5}$ \\
\hline
\end{tabular}

Table 1. Imaginative prose texts in CMSW

The occurrences of boy, girl, kid, lad(die), lass(ock)(ie), man, quean and woman were then counted in both CMSW and in the RLS corpus using Wordsmith Tools (Scott, 2004); vocative forms were identified on the basis of a close qualitative reading of the occurrences; finally, figures were normalized per 10,000 words. A summary of quantitative findings is offered in Tables 2a and $2 \mathrm{~b}$ below; data is presented giving special attention to normalized frequencies in vocative forms (fifth column):

\begin{tabular}{|l|r|r|r|r|}
\hline & \multicolumn{2}{|c|}{ Absolute figures } & \multicolumn{2}{c|}{$\begin{array}{c}\text { Normalized frequencies } \\
\text { per 10,000 words }\end{array}$} \\
\hline \multicolumn{1}{|c|}{ Item } & Total occurrences & \multicolumn{1}{c|}{$\begin{array}{c}\text { Occurrences } \\
\text { in vocative forms }\end{array}$} & $\begin{array}{c}\text { Total occurrences } \\
\text { Occurrences vocative forms }\end{array}$ \\
\hline Boy & 584 & 163 & 4 & 1.1 \\
\hline Man & 4464 & 150 & 30.5 & 1 \\
\hline Lad(die) & 422 & 59 & 2.9 & 0.4 \\
\hline Girl & 414 & 25 & 2.8 & 0.2 \\
\hline Woman & 385 & 10 & 1.2 & 0.1 \\
\hline Lass(ock)(ie) & 176 & 18 & 0.03 & 0.1 \\
\hline Quean & 4 & 0 & 0 & 0 \\
\hline Kid & 1 & 0 & & 0 \\
\hline
\end{tabular}

Table 2a. Occurrences in the RLS corpus 


\begin{tabular}{|l|r|r|r|r|}
\hline & \multicolumn{3}{|c|}{ Absolute figures } & \multicolumn{2}{c|}{$\begin{array}{c}\text { Normalized frequencies } \\
\text { per 10,000 words }\end{array}$} \\
\hline \multicolumn{1}{|c|}{ Item } & Total occurrences & $\begin{array}{c}\text { Occurrences } \\
\text { in vocative forms }\end{array}$ & Total occurrences & $\begin{array}{c}\text { Occurrences } \\
\text { in vocative forms }\end{array}$ \\
\hline Man & 2440 & 162 & 21 & 1.4 \\
\hline Lad(die) & 189 & 47 & 1.6 & 0.4 \\
\hline Woman & 360 & 33 & 3.1 & 0.3 \\
\hline Boy & 294 & 34 & 2.5 & 0.3 \\
\hline Lass(ock)(ie) & 264 & 27 & 1.4 & 0.2 \\
\hline Girl & 167 & 18 & 0.1 & 0.2 \\
\hline Kid & 8 & 0 & 0.1 & 0 \\
\hline Quean & 8 & 0 & & 0 \\
\hline
\end{tabular}

Table 2b. Occurrences in CMSW

\section{RESULTS}

A preliminary overview of the data in Tables $2 \mathrm{a}$ and $2 \mathrm{~b}$ above shows that man, boy and lad(die) are, perhaps predictably, very frequent vocative forms in both corpora; at the other end of the spectrum, kid and quean are remarkably less frequent: while kid may be said to have acquired a vocative value at a later time ${ }^{5}$, it is possible that -in the nineteenth centuryuses of quean were perhaps too restricted from the geographical point of view to feature consistently in either corpus. As for the other items, they may be worth discussing in greater detail. The relatively much higher frequency of boy as a vocative form in the RLS corpus may be attributed to the fact that, in many texts, the protagonist is indeed a boy, while female characters are notoriously less prominent throughout Stevenson's prose fiction. Examples relating to man, woman, boy and girl (in both corpora) are given below:

3. 'Whoy, Dickie, my man, thou hast been a very good lad, [...]' (CMSW)

4. "Ye wud need to come in aboot to the toon at ony rate, Dawvid, man, afore we cud speak aboot onything o' the kin'.” (CMSW)

5. Noo, dinna be mealy mou't, Dawvid, man, fan ye tell them. (CMSW)

6. “Mak nae apologies, Janet, my woman,” said David. (CMSW)

7. "Whoy, woman, what's thou on about? I’s sure I has plenty for thee and I baith! [...]"

(CMSW)

8. You are not the man, my boy, to whine over a dead ass; but you are the man, my boy, to be pensive over the very fear, however unfounded, of an empty jug (CMSW)

9. “Be not alarmed, pretty girl,” said a venerable gentleman; (CMSW)

10. "Why, man, you're shaking!” cried the officer. (RLS, The Wrecker)

11. "David," said he, "I love you like a brother. And O, man," he cried in a kind of ecstasy, “am I no’ a bonny fighter?” (RLS, K) 
12. "Ay, but Kirstie, my woman, you're asking me ower much at last," said Archie, profoundly moved (RLS, WH)

13. “Woman,” says he to Janet, "is this true?” “As the Lord sees me,” says she. (RLS, TJ)

14. "Nay, good boy, I have no arms, nor skill to use them if I had," replied the other

(RLS, The Black Arrow)

15. "Dick," she said, "ye sweet boy, ye must come and kiss me for that word. [...]"

(RLS, The Black Arrow)

16. My dear girl, we have to be wise. We must not wreck our lives at the outset.

(RLS, WH)

17. "Are you mad, girl?” he cried. "I bid you be silent and lead on.”

(RLS, The Dynamiter)

As for lad(die) and lass(ock)(ie), they appear to be even more interesting, as they are both socio-geographically marked and potentially more emphatic as far as their pragmatic value is concerned. The co-text in which instances of boy, girl, lad(die), lass(ock)(ie), (my) man and woman are recorded appears to show a greater density of Scots lexical items and/or grammatical features in the CMSW texts than in the RLS ones. The opposite is true when the vocative forms follow first names, and especially when the latter feature in their diminutive forms: see examples (30-49) below. In what follows, occurrences of these items will be discussed in relation to the syntactic context in which they are observed in an attempt to identify their contribution to the pragmatic force of the locution.

Looking at the instances recorded in both corpora, we see that vocatives are typically found in directive speech acts, as they draw the attention of the listener to the illocutionary force of the statement -see the following examples, in addition to (5, 6, 9, 15 and 16) above:

18. Now, lad, take ye thae news to your bed wi' ye (CMSW)

19. "How could you let him go, Janet?” "Lat him gang, laddie! [...]” (CMSW)

20. "Well, let 'em come, lad--let 'em come," said Silver, cheerily. "I’ve still a shot in my locker." (RLS, Treasure Island)

Vocatives may in turn be strengthened with the addition of the possessive adjective my and (on occasion) of a qualifying adjective. In such cases, the possessive adjective stresses the personal relationship existing between the participants, which, in turn, enhances their mutual positive face ${ }^{6}$ :

21. But, my laddie, min’ ye're nae to be bauch and chucken-heartit (CMSW)

22. But, my lad, you must never ask me to leave my father. (RLS, MM)

23. "Look here, my lass," said Alan, "there are boats in the kingdom of Fife [...]"

(RLS, K) 
It may not be accidental that, when an adjective is added, it often has a positive connotation, as in the examples below:

24. “Grizzy, my sonsy lass, come an’ gie me a lift wi’ the toop-heck; [...]” (CMSW)

25. “Janet, my bonnie lass” - and here David’s eyes beamed upon his wife (CMSW)

26. My dear laddie, why were nae you and Davie here? (RLS, The Wrecker)

However, the relationship between vocatives and face-enhancement strategies may also be manipulated for narrative reasons. In this respect, it is perhaps worth noting that the numerous instances of "Davie my man" in the words attributed to Ebenezer Balfour in K (see examples 39-42 below) sound grimly ironic when his role in the plot becomes clear.

In other cases, the qualifying adjective may follow the second person pronoun, in which case the pragmatic value of the vocative is more ambiguous: while on the surface it may sound like an insult, it may in fact highlight the contrast between two predications, as in (27) below, in which the idea of blindness is made to contrast with the inquiry into the ability to see the speaker's feelings -an indirect invitation to do so:

27. "Hate you!” cries I, and held her firm. "You blind lass, can you not see a little in my wretched heart? [...]” (RLS, C)

The vocative is thus seen to play a very important part also in expressive and representative speech acts; in such cases, the speaker elicits the listener's involvement in the predication, almost inviting him or her to share the world view that is expressed, though it may be close to a truism:

28. Eh, lassie, it's life and death. (RLS, Deacon Brodie)

29. Ah, lassie, it’s a wicked world. (RLS, Deacon Brodie)

\subsection{Diminutives and first name vocatives in the RLS corpus: qualitative findings}

In the instances that have been discussed so far, vocative forms are typically found in sentences in which they are used between or before commas, or before exclamation marks. In such cases, punctuation attempts to reproduce spoken phono-syntactic groups in an ad-hoc way, since the distinctions discussed here were not codified in grammars of written English. When vocatives follow first names, however, a more interesting syntactic pattern appears to emerge, as the first name and the vocative form (either or both with a diminutive suffix) are very seldom separated by a comma. In the RLS corpus the following instances are observed:

30. “Come, come, Hairry lad,” says he, with a broad accent (MB)

31. Charlie lad, they're a’ drunk in yon schooner, a’ dozened wi’ drink (MM) 
32. "What for would I go near it, Charlie lad? The poor souls are gone to their account long syne $[\ldots]$ ". (MM)

33. "Well, Davie lad,” said he, "I will go with you as far as the ford [...]” (K)

34. but, O Davie laddie, it's but a drop of water in the sea; it'll help you but a step (K)

35. “[...] And here, Davie laddie,” he resumed, "it lies near upon my conscience [...]” $(\mathrm{K})$

As we can see, there is never a comma between the name and lad(die): commas only occur when lad(die)(s) is a real vocative, as in "On board, lads, for your lives!" (RLS, The Black Arrow).

The corpus does not provide similar instances with $<$ name+lass(ie) $>$. However, fruitful comparisons can be made with $<$ name + boy $>$ and $<$ name + (my) man/woman $>$. Boy is typically preceded by (my) dear, but only in one case do we find Davie boy (K). As for my man, it might fit into the same syntactic pattern if the possessive adjective has a reduced vowel /mi/ or /mə/; in addition to examples (3) and (12), cited above, the following instances are recorded in the RLS corpus:

36. O, Davie man, dinna be a pompous gowk! (C)

37. “Eh, Charlie man, it’s grand!” he cried. "See to them!” (MM)

38. "Mary,” I cried in fear, “do ye no' like me?” "Oh, Charlie man,” she said, "is this a time to speak of it?” (MM)

39. We'll agree fine yet. And, Davie my man, if you're done with that bit parritch, I could just take a sup of it myself (K)

40. I’m your born uncle, Davie my man, and you my born nephew. (K)

41. "Na, na," said he, "I did na mean that. What's mine is yours, Davie my man, and what's yours is mine. [...]" $(\mathrm{K})$

42. He seemed to turn this over in his mind; and then, "Davie, my man," said he, "ye've come to the right bit when ye came to your uncle Ebenezer [...]" (K)

43. "David kens; David's a good lad. Ye see, David my man, yon wild Hielandman is a danger to the ship [...]" (K)

44. “So now, David man, be brisk!” (K)

45. "Mean? What do I mean? It’s extraordinar, David man," says he, "that you should be so mortal stupit.” (C)

46. If the day comes, David man, that I can find time and leisure for a bit of hunting (K)

47. “Wheesht, wheesht!” cried Alan. "Dinna say that! David man, ye ken----” (K) 
48. Ye see, David man, they'll be Hieland folk. (C)

49. "[...] The morn? what am I saying?--the day, I mean.” "Ay, Alan man, the day, sure enough,” said I (C)

\section{DISCUSSION}

The RLS corpus does not provide instances of first names and vocative forms, whether in full or in the diminutive, separated by a comma, except in the cases where we have the addition of possessive adjectives and (possibly) other qualifiers (see examples 3, 6, 12, 24, 25 and 42 above). However, the first book edition of K published by Cassell has "Well, Davie, lad, said he” (1886: 1) -a relatively unusual form which may reflect a change made by the Cassell's printer and not noted by the author. Although the author may have made the change himself in proofs or approved in proofs a change made by the printer, it is significant that the comma is missing both in the manuscript and in the earlier publication in the magazine Young Folks (see Dury, n.d.).

This is clearly not the place to attempt the solution of a particularly difficult editorial crux; however, this is probably indicative of the difficulty of analyzing vocative forms. On the one hand, the change would be plausible, because the vocative form could be seen to be equivalent to my lad, and might therefore be independent of the first name. On the other, the much more numerous instances of <name+vocative> without intermediate commas seem to indicate that the vocative reinforces the pragmatic value of the name. In addition, the presence of the diminutive stresses the tone of endearment expressed by the vocative, and vice versa.

Although grammars and dictionaries do not seem to codify this kind of usage, the instances discussed in this study may actually reflect a vernacular syntactic structure in which different elements (first names, vocative forms, and diminutive suffixes applied to one, the other, or both) reinforce their mutual pragmatic value and highlight both involvement and personalization while functioning as powerful attention-seeking devices.

This explanation might also account for the frequency of this construction in $\mathrm{K}$, in which the interaction between the protagonist, David Balfour, and other characters typically shows the coexistence of Scots and English forms in SSE, and frequently features Scots speakers interacting with English-speaking ones, thus exhibiting the kind of code-mixing and code-switching that is so important both in Scottish literary texts and in spoken usage, even to this day. In addition, this text appears to rely more on dialogue than other works by the same author, though of course another kind of investigation should be conducted if specific quantitative data were to be offered in this respect.

On the other hand, it should also be remembered that a literary text always 'imitates' dialogue, and though it may sound plausible and realistic, the author's stylistic choices are the basis on which constructions are selected and greater or lesser emphasis is given to certain lexical or morpho-syntactic traits. As a result, conclusions can never be anything but partial - 
restricted, that is, to the expressive world of a certain author, though it is of course possible to relate them to the stylistic habits of other authors and assess their consistency with each other, or their autonomy from each other. The contribution of corpus linguistic methods to the study of literary texts may thus prove very valuable for the investigation of such patterns and their specificities. At the same time, it should also be borne in mind that (unless only manuscript sources feature in the corpus) the possibility of editorial interventions should not be excluded, and that such interventions may actually disrupt or modify elements whose significance may be quite relevant, when more detailed studies are conducted on micro-level sequences, rather than on large-scale ones.

\section{CONCLUDING REMARKS}

In this paper a specific case has been investigated relying on a specially compiled corpus of literary texts. The issue of vocative and diminutive forms, their syntactic organization and their pragmatic value has been discussed by looking at instances in the prose fiction and drama of Robert Louis Stevenson in order to assess the specific contribution that such usage may give to the stylistic quality of the texts -texts in which the skilful blend of Scots and English features results in very convincing, authentic-sounding forms.

The study first presented an overview of such occurrences in the RLS corpus and in CMSW, a recently-launched corpus of which the nineteenth-century imaginative prose section functioned as a control corpus. This showed that vocative forms appear to be used differently when they follow first names: in such cases, the punctuation patterns -which indicate typical intonation groups and are seen to occur together with vocative forms-, are disrupted in favour of a more efficient pragmatic use of the vocatives themselves. While vocative forms are normally framed by commas or other punctuation marks, after first names they can follow two patterns: on the one hand, more rarely, they do occur between commas, thus functioning as discourse markers and indicating pauses; much more frequently, however, they follow the first names without the insertion of commas, suggesting a single syntactic-intonation group. Hence, they become attached to the first name and reinforce its pragmatic value. In practice, when they follow first names, items like lad(die) or lass(ie) seem to function as semi-suffixes, meant to stress the vocative quality of the first name. As a result, the recipient is addressed twice simultaneously: first with his/her own name -to which greater endearment may be attributed if a diminutive suffix is also used- and then with a general noun which highlights the place of the recipient in a certain social framework, i.e. the role that is attributed to him as a lad, a lass, a boy, a man, a woman, etc. This, in turn, may be further personalized with the addition of the possessive adjective my, which highlights the link with the speaker, and possibly- of a qualifier, such as dear, poor, or bonnie, which stresses the affective way in which the recipient is perceived. 
From the pragmatic point of view, such strategies prove very valuable as positive faceenhancing moves, strengthening the bonds between the speaker and the listener by means of an accurate selection of nouns, adjectives and even suffixes. In other contexts, the study of valedictory formulae in correspondence has shown the importance of adjective, superlative and noun selection ${ }^{7}$. Far from being empty lexical shells, such formulae synchretically encode the participants' mutual status, as not everybody can define themselves as 'a friend', as opposed to an 'obedient, humble servant', or indeed a 'most obedient, humble servant'. Letter writing manuals provided guidance in relation to what was appropriate, so that encoders could ensure that their message would be successful from both the transactional and the interactional points of view. In the case of spoken usage, however, the identification of pragmatic rules is much more difficult. Nor should it be forgotten that, when we look at literary texts, we are looking at constructed artefacts that attempt to imitate spontaneous usage. The study of corpora may thus enable us to look at a wide range of sources so as to investigate the patterns that may emerge in relation to lexical choices, syntactic features and pragmatic values. The way in which literary texts choose to represent usage may be a function of the author's linguistic sensitivity, but the intervention of editors and printers should not be excluded, and ought in fact to be considered carefully. In Stevenson's prose fiction, the use of diminutive and vocative forms has provided an interesting case study: this author's very high standard concerning the attention given to the Scots-English continuum throughout his work is certainly confirmed by a corpus-based investigation of his texts.

\section{NOTES}

1. DSL comprises the electronic editions of both the 12-volume Dictionary of the Older Scottish Tongue (DOST) and the 10-volume Scottish National Dictionary (SND). In the quotations from DSL reference will therefore be made to the specific branch of the online dictionary.

2. On the latter see for instance Dressler and Merlini Barbaresi (1994: 113), while Dossena (1998) focuses on the pragmatic value of diminutives in SSE.

3. The text of this ballad is available in the website of the National Library of Scotland: see MacNeil, H. (n.d.).

4. These volumes are made available as plain text files in the Gutenberg project.

5. The OED dates the first instance as a vocative form to 1926 - see 'kid, $\mathrm{n}^{1}$, , s.v., 5.d: “1926, J. Black You can't Win iv. 26 I'll tell you what I'll do with you, kid.”

6. Terminology follows Brown \& Levinson (1978).

7. See, for instance, Dossena and Tieken-Boon van Ostade (2008) and Dossena and Del Lungo Camiciotti (2012).

\section{REFERENCES}

Aitken, A. J. (1984a). Scottish accents and dialects. In P. Trudgill (Ed.), Language in the British Isles (pp. 94-114). Cambridge: Cambridge University Press.

Aitken, A. J. (1984b). Scots and English in Scotland. In P. Trudgill (Ed.), Language in the British Isles (pp. 517-532). Cambridge: Cambridge University Press. 
Aitken, A. J. (1992). Scots. In T. McArthur (Ed.), The Oxford Companion to the English Language (pp. 893-898). Oxford: Oxford University Press.

Booth, B. A. \& Mehew, E. (Eds.). (1994/1995). The Letters of Robert Louis Stevenson. New Haven: Yale University Press.

Brown, P. \& Levinson, S. C. (1978). Politeness: Some Universals in Language Usage. Cambridge: Cambridge University Press.

Bulloch, J. M. (1921/1970). The delight of the Doric in the diminutive. In W. A. Craigie (Ed.), The Scottish Tongue (pp. 125-151). College Park: McGrath.

CMSW, The Corpus of Modern Scottish Writing, http://www.scottishcorpus.ac.uk/cmsw/.

Dorian, N. (1993). Internally and externally motivated change in language contact settings: Doubts about dichotomy. In C. Jones (Ed.), Historical Linguistics: Problems and Perspectives (pp. 131155). London: Longman.

Dossena M. (1998). Diminutives in Scottish Standard English: A case for comparative linguistics? Scottish Language, 17, 22-39.

Dossena M. (2005). Scotticisms in Grammar and Vocabulary. Edinburgh: John Donald (Birlinn).

Dossena M. (In preparation). "Stour or dour or clour": An overview of Scots usage in Stevenson's works and correspondence. In J. Kirk (Ed.), Scots: The Language and its Literature - A Festschrift for J. Derrick McClure. Amsterdam: Rodopi.

Dossena, M. \& Del Lungo Camiciotti, G. (Eds.). (2012). Letter Writing in Late Modern Europe. Amsterdam: Benjamins.

Dossena, M. \& Tieken-Boon van Ostade, I. (Eds.). (2008). Studies in Late Modern English Correspondence: Methodology and Data. Bern: Peter Lang.

Dressler, W. U. \& Merlini Barbaresi, L. (1994). Morphopragmatics: Diminutives and Intensifiers in Italian, German, and Other Languages. Berlin: Mouton de Gruyter.

DSL, Dictionary of the Scots Language, http://www.dsl.ac.uk/.

Dury, R. (1992). Saxonism and the preference for 'native' vocabulary. In N. Pantaleo (Ed.), Aspects of English Diachronic Linguistics (pp. 133-146). Fasano: Schena.

Dury, R. (Compiler) (n.d.). List of the Collected Editions of Robert Louis Stevenson's Works, http://edrls.wordpress.com/2011/12/12/what-are-you-reading-workshop-nls-dec-7th-2011/.

Fenton, A. (1995). Craiters... Or Twenty Buchan Tales. East Linton: Tuckwell Press.

Macafee, C. (1994). Traditional Dialect in the Modern World: A Glasgow Case Study. Frankfurt am Main: Peter Lang.

MacNeil, H. (n.d.). Come under my Plaidie. In The Word on the Street, http://digital.nls.uk/broadsides/broadside.cfm/id/14949.

McClure, J. D. (1987). 'Lallans' and 'Doric' in North-Eastern Scottish poetry. English World-Wide, $8(2), 215-234$.

McClure, J. D. (1993). Varieties of Scots in recent and contemporary narrative prose. English WorldWide, 14(1), 1-22.

McClure, J. D. (1994). English in Scotland. In R. Burchfield (Ed.), The Cambridge History of the English Language, 5 (pp. 23-93). Cambridge: Cambridge University Press.

Miller, J. (1993). The grammar of Scottish English. In J. Milroy \& L. Milroy (Eds.), Real English: The Grammar of English Dialects in the British Isles (pp. 99-138). London: Longman.

Milton, C. (1992). Language, class and education in twentieth-century Scottish writing. English World-Wide, 13(2), 219-251.

OED, Oxford English Dictionary, www.oed.com.

RLS, Lang, A. (1911-2), Works by R.L. Stevenson. London: Chatto \& Windus. (Swanston Edn. Retrieved from http://www. gutenberg.org/).

SCOTS, The Scottish Corpus of Text and Speech, http://www.scottishcorpus.ac.uk/.

Scott, M. (2004). WordSmith Tools 4.0. Oxford: Oxford University Press.

Stevenson, R. L. (1885). A Child's Garden of Verses. London: Longmans, Green, and Co.

Stevenson, R. L. (1886). Kidnapped. London: Cassell and Co.

Stevenson, R. L. (1887). Underwoods. London: Chatto and Windus.

Tulloch, G. (1997). Lexis. In C. Jones (Ed.), The Edinburgh History of the Scots Language (pp. 378432). Edinburgh: Edinburgh University Press. 